\title{
EDTTORIAL
}

\section{ESPIROQUETOSE INTESTINAL HUMANA}

A espiroquetose intestinal, uma entidade clínico-patológica descrita mundialmente há anos, parece ser pouco conhecida no Brasil. Sua importância é crescente não apenas como uma possível causa de diarréia crônica mas como eventual oportunista em imunosuprimidos.

Desde o final do século passado, sabia-se que espiroquetas estavam presentes nas fezes de vârios animais, incluindo o macaco e o homem. Excelentes apanhados históricos sobre a espiroquetose intestinal estão nos trabalhos de Takeuchi e $\operatorname{cols}^{23}$ e Tegljaerg ${ }^{24}$.

No Brasil, trabalhos de Lins em $1924^{16}$ e de Gomes e Pessoa em $1926^{\circ}$ revelaram a presença de espiroquetas nas fezes de pacientes com diarréia e que melhorava após o tratamento específico da época.

O exame da literatura demonstra, que a espiroquetose intestinal compreende duas condições distintas: uma menos importante, representada por espiroquetas que são recuperadas das fezes e a outra, mais importante, descrita inicialmente por Harland e Lee ${ }^{k_{1}}$ e por Lee e $\operatorname{cols}^{12}$ que se refere a demonstração das espiroquetas en intenso contato com os enterócitos do intestino grosso e apêndice. Esta condição é a que realmente é a mais importante sob o ponto de vista clínico-patológico e pressupõe um parasitismo da mucosa. Em parte dos casos os espiroquetas não determinam sintomatologia aparente; entretanto, quando fatores do hospedeiro alteram o balanço da flora intestinal, existe um crescimento excessivo dos mesmos, com patogenicidade evidente.

A espiroquetose intestinal como descrita por Harland e Lee ${ }^{10}$ e Lee e cols ${ }^{12}$ é usualmente diagnosticada em biópsias e/ou espécimens cirúrgicos por colorações de rotina, como a hematoxilina eosina. Colorações pela prata põem em evidência mais facilmente o parasita $e$, mais recentemente, as técnicas imuno-histoquímicas, permitem não só melhor visualização dos

Instituto de Medicina Tropical de São Paulo da Universidade de São Paulo (USP), Hospital Universitário (USP) e Instituto Adolfo Lutz (Secretaria de Saúde do Estado de São Paulo), São Paulo, SP, Brasil.

Este projeto recebeu apoio parcial do CNPq (300857/94-2). Recebido para publicação em 17/01/95.

\section{HUMAN INTESTINAL SPIROCHETOSIS}

Human intestinal spirochetosis, a world-wide clinico-pathological condition, is not well known in Brazil. Its importance is related not only to chronic diarrhea but as a possible opportunistic infection in immunosuppressed patients

Since the end of the last century spirochetes are known to be present in the feces of various animal species, including the monkey and man. Good historical surveys of spirochetosis of the digestive tract are covered in the works of Takeuchi et al ${ }^{23}$ and Teglbjaerg ${ }^{24}$.

In Brazil, early reports by Lins in $1924^{16}$ and by Gomes and Pessoa in $1926^{8}$ demonstrated the presence of spirochetes in the feces of patients with diarrhea which subsided after treatment.

Published reports seem to cover two conditions of intestinal spirochetosis; one concerns spirochetes recovered from feces and the other, first described by Harland and Lee ${ }^{10}$ and Lee et $\mathrm{al}^{12}$, refers to the demonstration of spirochetes attached to mucosal surfaces. Our cases belong to this latter condition and, as far as we could ascertain, are the first reported in Brazil.

Human intestinal spirochetosis, as described by Harland and Lee ${ }^{10}$ and Lee et $\mathrm{al}^{12}$, is routinely detected by ordinary staining techniques such as hematoxylin-eosin, in biopsies and surgical specimens. The presence of spirochetes can be confirmed by using silver stains. More recently immunohistochemical procedures using both anti-treponemal and anti-leptospire sera were shown to cross-react with spirochetal antigen/s and consequently to facilitate the diagnosis of intestinal spirochetosis.

Hematoxylin-eosin discloses the presence of a $3 \mu \mathrm{m}$ thick hematoxyphilic, fuzzy layer on the luminal surface of the epithelial cells of the rectum, colon and appendix. Transmission and scanning electron microscopy also have been used to demonstrate the spirochetes attached to the epithelial surfaces. Many spirochetes are seen with tapered ends oriented at right angles to the epithelial surface and attached end-on to the luminal cell membrane between the microvilli. The spirochetes measure, 3 to $4 \mathrm{\mu m}$ in length and $0.2 \mu \mathrm{m}$ in width. The microvilli appear shortened or even depleted in proportion to the density of the attached spirochetes. The epithelial surface membrane at the attachment site is depressed to form a small, electron-lucent pit between the tip 
parasitas como, ocasionalmente, demonstram depósitos antigênicos em enterócitos e/ou células apresentadoras de antígeno na mucosa. Soros policlonais produzidos em coelho contra $T$. pallidum ou leptospira cruzam com antígenos dos espiroquetas e são aqueles usados durante procedimentos imunohistoquímicos em tecidos.

Pela hematoxilina-eosina, os espiroquetas aparecem como uma franja hematoxilínica recobrindo a superfície do enterócito. O patologista precisa se familiarizar com este aspecto, que passa frequentemente desapercebido ou então é confundido com depósito de material mucóide. Só a observação cuidadosa vai evidenciar a presença de formações alongadas ou ovalares, quando cortadas transversalmente, basofílicas, e que correspondem aos acúmulos parasitários. Estes podem se dispor focalmente, poupando os orifícios de células mucosas, ou, como nos casos mais graves com sintomatologia aparente, de forma difusa. A microscopia eletrônica de transmissâo evidencia facilmente os parasitas que medem 3 a $4 \mu \mathrm{m}$ de comprimento e $0,2 \mu \mathrm{m}$ de espessura. Eles estão recobertos por duas membranas, uma unida ao corpo parasitário (membrana periplasmática) e outra mais externa. Seis a oito flagelos são freqüentemente detectados no espaço entre as membranas. O corpo do parasita contem ácidos nucléicos e ribosomas. A microscopia de varredura evidencia de maneira extremamente elegante a superfície dos enterócitos totalmente recoberta pelos espiroquetas, com obliteração e alteração dos microvilos.

Como as técnicas bacteriológicas para a identificação dos espiroquetas intestinais são extremamente difíceis os métodos histológicos de rotina têm sido considerados como suficientes para o diagnóstico desta condição. Entretanto, microbiologistas principalmente aqueles dos países escandinavos, foram capazes de demonstrar características de crescimento do parasita que, juntamente com sua morfologia, justificam uma nova designação. O nome proposto foi o de Bracbyspira aalborgi $i^{11}$. Mais recentemente, outros espiroquetas foram isolados e caracterizados não só por aspectos de seu crescimento e de sua ultra-estrutura, como também através de características genéticas ${ }^{26913}$

A espiroquetose intestinal parece estar distribuida mundialmente, mas sua freqüência difere de um país para outro. Está presente em 2,5-9\% em um estudo de biópsia da Escandinávia e Inglaterra ${ }^{15}$. Na Europa do Norte, a condição é vista em 3-9\% de todos os pacientes submmetidos of the organism and the cell membrane. The spirochetes themselves were enveloped by two asymmetrical unit membranes, the outer leaflets slightly thickened and more electron dense than the inner leaflets. Ribosomes and nuclear material can be recognised within the cells. Six to eigh flagella located in the periplasmic space are particularly visible in transverse sections of the parasite.

Bacteriological techniques for the identification of intestinal spirochetes have been difficult to carry out and ordinary staining techniques were considered sufficient for the histological diagnosis of the conditions. However, successful isolation, cultivation and propagation of spirochetes from feces or from human rectal biopsies have been reported. The growth characteristics and the morphology of the spirochetes differ sufficiently from previously isolated treponemes to justify a new designation, and the name Brachyspira aalborgi has been proposed for the new type species isolated in the Scandinavian countries ${ }^{11}$. Other spirochetes were distinguisable by ultrastructural and growth aspects ${ }^{269}$ and by genetic characterization ${ }^{13}$.

Human intestinal spirochetosis appears to be a world-wide condition, but its geographical distribution varies considerably as judged histologically and by electron microscopy. It was present at a frequency of $2.5-9 \%$ in an unselected biopsy series from Scandinavia and Great Britain $^{15}$. In Northern Europe, the condition is seen in 3-9\% of all patients referred for colonoscopic biopsies ${ }^{14}$; an unusually high frequency of $16.5 \%$ has been reported from Greece ${ }^{6}$. Takeuchi et $\mathrm{a}^{23}$ reported a frequency of intestinal spirochetosis of $1.9 \%$ in the USA. Examining 282 biopsies of colon, most of them obtained by colonoscopy we found a frequency of $1.41 \%$. This figure, however, probably understimates the real frequency of the condition in Brazil since surgical specimens were not included in the study. The frequency of intestinal spirochetosis in the appendix varies from $7.8 \%$ to $12.8 \%$ as reported in Argentina, England, Sweden and Denmark ${ }^{12172025}$

The pathological potential and clinical significance of human intestinal spirochetosis is still controversial. Indeed, several reports have considered these organisms to be commensals of the gastrointestinal $\operatorname{tract}^{121924}$. Other studies have suggested that intestinal spirochetosis may cause rectal discharge, rectal bleeding and diarrhea and that the succesful treatment of intestinal 
a colonoscopia e biopsiados ${ }^{1 i}$. Uma freqüência particularmente alta, de $16,5 \%$, é referida na Grécia ${ }^{6}$. Nos Estados Unidos, o trabalho de Takeuchi e cols ${ }^{23}$ aponta uma freqüência de $1,9 \%$. Nosso estudo, compreendendo 282 biópsias de colon, a maior parte delas obtidas através de colonoscopia, em pacientes com diferentes patologias, revelou uma freqüência de $1,4 \%$. Acreditamos, contudo, que a freqüência deva ser maior, uma vez que nosso material não compreendeu espécimens cirúrgicos tais como produtos de colectomia e apêndice. A freqüência de espiroquetose no apêndice cecal varia de 7,8 a $12,3 \%$ como visto na Argentina, Inglaterra, Suécia e Dinamarca' ${ }^{12} 2025$.

O papel patogênico das espiroquetas no homem é ainda controverso. Muitos os consideram como simples comensais, sem nenhuma capacidade de determinar lesões, e/ou manifestações clínicas $^{12}{ }^{19}{ }^{24}$. Entretanto, outros estudos sugerem que a espiroquetose intestinal pode se manifestar clinicamente, particularmente por sangramento intestinal e diarréia. Nestes casos o tratamento da espiroquetose, principalmente através do metradianazol, melhora os sintomas clínicos ${ }^{3-21}$. O dano de enterócitos, particularmente de seus microvilos e a penetração de espiroquetas na lâmina própria são considerados como o substrato anatomopatológico dos sintomas clínicos. Gad e cols', entretanto, relacionam a patogenecidade dos microorganismos a intensidade da infecção e sugerem que a presença da camada espessa de parasitas sobre o epitélio age como barreira mecânica aos processos de reabsorção levando à diarréia aquosa.

Nossa experiência demonstra que, dos quatro pacientes diagnosticados, em três os sintomas clínicos não eram relacionados à espiroquetose. Em uma paciente, entretanto, que apresentava diarréia crônica, com acentuada perda de peso, a infecção pelos espiroquetas era mais disseminada; o tratamento específico levou a suspensão da diarréia e recuperação da paciente. Biópsias controles revelaram o desaparecimento dos espiroguetas, sugerindo uma relação causa-efeito entre a parasitose e a sintomatologia clínica. Aparentemente, não existem aspectos colonoscópicos típicos desta infecção do trato intestinal.

A alta prevalência (30 a 36\%) de espiroquetose em homosexuais masculinos com diarréia deve nos alertar para a possibilidade de um novo oportunista ${ }^{31822}$. Não existem, en nosso meio, estudos da freqüência desta infecção, em spirochetosis improves these clinical symptoms ${ }^{37}$ ${ }^{21}$. Damage to epithelial cells and the penetration of the spirochetes into the lamina propria with engagement of macrophages have been described $^{1}$ and are considered to be the primary cause of the clinical symptoms. Gad et al ${ }^{7}$ ascribed the pathogenecity of the microorganisms to the extent and degree of infection. These authors suggest that the presence of a thick layer of organisms on the surface epithelium of the colon may act as a mechanical barrier to the reabsorptive processes in the large bowel lumen, leading to the watery diarrhea.

In three of our four patients, the main clinical symptoms were unrelated to spirochetosis and therefore the spirochetes may be regarded as inocuous commensals. However, in one patient with marked chronic diarrhea, parasites were more disseminated. Since this patient improved after metronidazole treatment and the spirochetes disappeared from the control biopsy it is possible that in this particular case the diarrhea may have been caused by the spirochetal infection. Colonoscopic findings are non-specific in intestinal spirochetosis.

The high prevalence ( 30 to $36 \%$ ) of intestinal spirochetosis in homosexual men accompanied by more extensive histopathological changes and diarrhea should be regarded as an alert for the presence of another oportunistic infection in immunosuppressed patients ${ }^{21822}$. There are not studies among us of the frequency of intestinal spirochetosis in immunosuppressed patients of different causes.

In conclusion, intestinal spirochetosis is usually a harmless infection of the gastrointestinal tract, but under certain. circunstances involving particularly the host defense system, there is an overgrowth of the spirochetes which may then become pathogenic. 
homossexuais, aidéticos e mesmo em imunosuprimidos por outras causas.

Desta maneira, a espiroquetose intestinal parece ser usualmente uma infecção que não determina manifestações clínicas principalmente em pacientes com sistema imunitário sadio. Entretanto, determinados fatores do hospedeiro envolvendo ou não eventual queda do estado imunitário podem levar a um crescimento excessivo do parasita que, então, poderá se tornar patogênico

\section{REFERÊNCIAS BIBLIOGRÁFICAS}

1. Antonakopoulos G, Newman J, Wilkinson M. Intestinal spirochetosis: an electron microscopic study of an unusual case. Histopathology 6:477-488, 1982.

2. Cooper C, Cotton DW, Hudson MJ, Kirkham N, Wilmott FE. Rectal spirochetosis in homosexual men: characterisation of the organism and pathophysiology. Genitourinary Medicine 62:47-52, 1986.

3. Crucioli V, Busuttil. Human intestinal spirochetosis. Scandinavian Journal of Gastroenterology 70:177-179, 1981.

4. Cotton DW, Kirkham N, Hicks DA. Rectal spirochetosis. British Journal Venereal Diseases 60:106-109, 1984.

5. Dauzan YR, Mertio JPH, Grelier P, IP Kan Fong $H$, Dachary D, Goussot JF, Mascarel A. La spirochétose colorectale: une entité anatomo-pathologique? Annales de Pathologie 10:258-261, 1990

6. Delladetsima, K, Markaki S, Papadimitriou K. Intestinal spirochetosis. Light and electron microscopic study. Pathology, Research and Practice 182:780-782, 1987.

7. Gad A, Willén R, Furugard $K$, Fors B, Hradsky $M$. Intestinal spirochetosis as a cause of long standing diarrhea. Upsala Journal Medical Sciences 82:49-54 1977.

8. Gomes JM, Pessoa SB. Um caso de dyarrhea dysenteriforme grave provocada por espirochetas.Anais Paulistas de Medicina e Cirurgia 14:167-169, 1926.

9. Guccion JG, Benator DA, Zeller J, Termanini B, Saini $N$. Intestinal spirochetosis and acquired immunodeficiency synndrome: ultrastructural studies of two cases. Ultrastructural Pathology 19:15-22, 1995.

10. Harland WA, Lee FD. Intestinal spirochetosis. British. Medical Journal 3:718-719, 1967.

11. Hovind-Hougen $\mathrm{K}$,Andersen AB, Nielsen RH, Orholm M, Pedersen JO Teglbjaerg PS, Thaysen EH. Intestinal spirochetosis: morphological characterization and cultivation of the spirochete Bracbyspira aalborgigen. nov, sp. nov. Journal of Clinical Microbiology 16:1127$1136,1982$.

12. Lee FD, Krazzewski A, Gordon J, Howie JGR, McSeveney D, Harland WA. Intestinal spirochetosis. Gut 12:126-133, 1971.

13. Lee JI, Hampson DJ. Genetic characterisation of intestinal spirochaetes and their association with disease. Journal Medical Microbiology 40:365-371, 1994.

14. Lindboe CF, Tostrup NE, Nersund R, Rekkavik G. Human intestinal spirochaetosis in mid - Norway. A restropective histopathological study with clinical correlations. APMIS 101:858-864, 1993.

15. Lindboe CF, Engesvoll I, Darell M, Kopstad G. Immunoglobulin containing cells in the colonic mucosa in patients with human intestinal spirochetosis. APMIS 102:849-854, 1994

16. Lins A Sobre o Spirocheta eurygyrata e a dysenteria espirillar. Arquivos Brasileiros de Medicina 14:420426, 1924.

17. Mazza S. Espiroquetosis apendiculares. La Prensa Medica Argentina 17:464-468, 1930.

18. Nathwani D, Green ST, Boyd JD. Intestinal spirochaetosis in a man with acquired immune deficiency syndrome (AIDS). Journal of Infection 21:318-319, 1990.

19. Nielsen RH, Orholm M, Pedersen JO, Hovind-Hougen $K$ Teglbjaerg PS, Thaysen EH. Coloretal spirochetosis: clinical significance of the infestation. Gastroenterology 85: 62-67, 1983.

20. Nielsen RH, Lundbeck FA, Teglbjaerg PS, Ginnerup P, Hovind-Hougen $\mathbf{K}$. Intestinal spirochetosis of the vermiform appendix. Gastroenterology 88: 971-977, 1985. 
Editorial. Brito T, Sandoval MP, Silva $A G$, Saad RC, Colaiacovo W. Espiroquetose intestinal bumana. Revista da Sociedade Brasileira de Medicina Tropical 29:313-317, jul-ago, 1996.

21. Rodgers FG, Rodgers C, Shelton AP, Hawkey CJ. Proposed pathogenic mechanism for the diarrhea associated with human intestinal spirochetes.American Journal Clinical Pathology 86:679-682, 1986.

22. Surawicz CM, Roberts PL, Rompalo A, Quinn TC, Homes $\mathrm{KK}$, Stamm WE. Intestinal spirochetosis in homosexual men. American Journal of Medicine 82:587-59 1987.

23. Takeuchi A, Jervis HR, Nakazawa $H$, Robinson DM. Spiralshaped organisms on the surface colonic epithelium of the monkey and men. American Journal of Clinical Nutrition 27:1287-1296, 1974.

24. Teglbaerg PS. Intestinal spirochaetosis. Current topics in Pathology 81:247-256, 1990.

25. Willén $R$, Carlén $B$, Cronstedt $J$, Willén $H$. Intestinal spirochetosis of the colon diagnosed with colonoileoscopy and multiple biopsies. Endoscopy 17:86-88, 1985.

Thales De Brito

Marina P. Sandoval

Ana G. Silva

R.C. Saad e

W. Colaiacovo 